\title{
PENINGKATAN KEMAMPUAN GURU DALAM MENERAPKAN PENDEKATAN PEMBELAJARAN SAINTIFIK PADA KURIKULUM 2013 MELALUI LESSON STUDY DI SDN SUMBERSARI 3 MAESAN BONDOWOSO
}

\author{
Didik Tripuji Suharyadi \\ SDN Sumbersari 3 Maesan Bondowoso \\ tripujididik9@gmail.com
}

\begin{abstract}
Learning with a scientific approach can provide understanding to students in recognizing and understanding various materials using a scientific approach. The purpose of this study is to improve the ability of teachers to apply a scientific learning approach through Lesson Study. The method used is a School Action Research (PTS) which is carried out by the Principal to improve the ability of teachers to apply scientific learning. The subject of the research was SDN Guru Sumbersari 3 Maesan Bondowoso, totaling 8 people. PTS lasts up to 2 cycles, which consist of: planning, action, observation and reflection. Data collection techniques through documentation, observation and teacher product assessment. From the results of the study, it can be concluded that the application of the Lesson Study learning model can improve the ability of teachers to carry out scientific learning in the 2013 curriculum at SDN Sumbersari 3 Maesan Bondowoso. This is supported by the results of observations in each cycle where there is an increase in the average value of 81 in cycle 1 and increases to 91 in cycle 2 with a very good description of the criteria.
\end{abstract}

Keywords: teacher ability, scientific learning, lesson study

\begin{abstract}
Abstrak: Pembelajaran dengan pendekatan saintifik dapat memberikan pemahaman kepada peserta didik dalam mengenal dan memahami berbagai materi dengan menggunakan pendekatan ilmiah. Tujuan penelitian ini adalah untuk meningkatkan kemampuan guru dalam menerapkan pendekatan pembelajaran saintifik melalui Lesson Study. Metode yang digunakan adalah Penelitian Tindakan Sekolah (PTS) yang dilaksanakan oleh Kepala Sekolah untuk meningkatkan kemampuan guru dalam menerapkan pembelajaran saintifik. Subjek penelitian adalah SDN Guru Sumbersari 3 Maesan Bondowoso yang berjumlah 8 orang. PTS berlangsung hingga 2 siklus, yang teridiri dari: perencanaan, tindakan, observasi dan refleksi. Teknik pengumpulan data melalui dokumentasi, observasi dan penilaian produk guru. Dari hasil penelitian dapat disimpulkan bahwa penerapan model pembelajaran Lesson Study dapat meningkatkan kemampuan guru dalam melaksanakan pembelajaran saintifik pada kurikulum 2013 di SDN Sumbersari 3 Maesan Bondowoso. Hal ini didukung dengan hasil pengamatan pada setiap siklus dimana terjadi peningkatan rata-rata nilai 81 pada siklus 1 dan meningkat menjadi 91 pada siklus 2 dengan keterangan kriteria sangat baik.
\end{abstract}

Kata kunci: kemampuan guru, pembelajaran saintifik, lesson study 


\section{PENDAHULUAN}

Pembelajaran dengan pendekatan saintifik dapat memberikan pemahaman kepada peserta didik dalam mengenal dan memahami berbagai materi dengan menggunakan pendekatan ilmiah Pendekatan saintifik dapat menjadikan siswa lebih aktif dalam mengkonstruksi pengetahuan dan keterampilannya (Chuntala, 2019). Selain itu, dapat mendorong siswa untuk melakukan penyelidikan guna menemukan fakta-fakta dari suatu fenomena dan membiasakan siswa menemukan kebenaran ilmiah yang berbasis fakta. Sehingga siswa mudah memahami konsep materi dengan baik dan kemampuan literasi menjadi meningkat (Mustakim \& Jumini, 2020).

Pendekatan saintifik lebih dikenal dengan sebutan pendekatan ilmiah. Secara umum pendekatan saintifik tersusun atas beberapa langkah kegiatan berurutan, ialah: mengamati, menanya, mengumpulkan informasi, melakukan percobaan, mengolah data, serta mengomunikasikan hasil (Setiawan, 2019). Hakekatnya pendekatan pembelajaran saintifik merupakan upaya pemahaman, penyadaran, dan pengembangan nilai positif tentang fenomena alam dan sosial yang meliputi produk dan proses (Daryanto \& Sudjendro, 2014). Pen- dekatan saintifik menjadikan pembelajaran lebih aktif dan tidak membosankan. Siswa dapat mengonstruksi pengetahuan dan keterampilannya melalui fakta-fakta yang ditemukan dalam penyelidikan dilapangan (Wibowo, 2017). Mahsun (2013) mengungkapkan bahwa dalam kegiatan pembelajaran, proses berpikir sistematis, terkontrol, empiris, dan kritis merupakan ciri-ciri pendekatan ilmiah atau saintifik

Pembelajaran saintifik diharapkan dapat menciptakan pembelajaran yang mengedepankan kondisi siswa berperilaku ilmiah dengan melakukan lima keterampilan ilmiah. Pembelajaran berbasis pendekatan saintifik mengarahkan siswa untuk mampu merumuskan masalah (dengan banyak menanya), bukan hanya dapat menjawab saja. Siswa akan dilatih berpikir analitis bukan mekanistis (hanya mendengar dan menghafal semata) selama pembelajaran. Majid (2014) menambahkan bahwa dalam pembelajaran berbasis pendekatan ilmiah/saintifik juga menekankan pentingnya kolaborasi dan kerjasama antar siswa dalam menyelesaikan setiap permasalahan dalam pembelajaran. 
Dengan demikian pendekatan saintifik/ilmiah adalah pendekatan pembelajaran yang berupaya memberikan pemahaman dan penyadaran kepada siswa tentang materi yang dipelajari (fenomena alam dan sosial) yang meliputi produk dan proses melalui kegiatan berpikir analitis dengan melakukan keterampilan ilmiah. Pendekatan saintifik menggunakan langkah-langkah serta kaidah ilmiah dalam proses pembelajarannya. Langkah ilmiah yang diterapkan meliputi menemukan masalah, merumuskan masalah, mengajukan hipotesis, mengumpulkan data, menganalisis data, dan menarik kesimpulan (Musfiqon \& Nurdyansyah, 2015). Oleh karena itu penerapan pemebelaran dengan pendekatan saintifik begitu penting diterapkan untuk mencapai tujuan pembelajaran.

Namun demikian masih banyak ditemukan di lapangan, kususunya di SDN Sumbersari 3 kecamatan Maesan kabupaten Bondowoso para guru masih mengalami kesulitan dalam menerapkan pembelajaran dengan menggunakan pendekatan saintifik. Sesuai dengan kegiatan observasi yang dilakukan oleh kepala sekolah masih banyak ditemukan kendala dalam menerapkan pendekatan pembelajaran saitifik di sekolah. Guru tidak pernah berpikir tentang minat dan perhatian siswa selama pembelajaran. Pada situasi lain ditemukan rencana pembelajaran (RPP) dibuat jika akan ada supervisi dari kepala sekolah dan dibuat sekadar memenuhi kewajiban administratif. Pembelajaran yang dilakukan di dalam kelas berbeda dengan RPP yang dipersiapkan. Data hasil observasi dapat dilihat pada tabel berikut:

Tabel 1. Rekapitulasi hasil pengamatan terhadap pelaksanaan pembelajaran di kelas dengan menerapkan pendekatan pembelajaran saintifik sebelum tindakan

\begin{tabular}{clccc}
\hline No & \multicolumn{2}{c}{ Aspek penilaian } & $\begin{array}{c}\text { Jumlah } \\
\text { skor }\end{array}$ & $\begin{array}{c}\text { Rata- } \\
\text { rata }\end{array}$ \\
\hline 1 & Memfasilitasi dan menyajikan kegiatan untuk mengamati & 18 & 56 \\
\hline 2 & Memfasilitasi dan menyajikan kegiatan untuk bertanya & 20 & 63 \\
\hline 3 & $\begin{array}{l}\text { Memfasilitasi dan menyajikan kegiatan untuk } \\
\text { mengumpulkan informasi }\end{array}$ & 17 & 53 \\
\hline 4 & $\begin{array}{l}\text { Memfasilitasi dan menyajikan kegiatan untuk } \\
\text { mengasosiasikan data dan informasi yang dikumpulkan }\end{array}$ & 18 & 56 \\
\hline $\begin{array}{l}\text { Memfasilitasi dan menyajikan kegiatan untuk } \\
\text { mengkomunikasikan pengetahuan dan keterampilan yang } \\
\text { diperolehnya }\end{array}$ & 20 & 63 \\
\hline \multicolumn{6}{c}{ Jumlah skor } & $\mathbf{9 3}$ & $\mathbf{2 9 1}$ \\
\hline \multicolumn{6}{c}{ Skor maksimal } \\
\hline Rata-rata & $\mathbf{1 5 1}$ & $\mathbf{5 0 0}$ \\
\hline Kriteria & $\mathbf{5 8}$ \\
\hline
\end{tabular}


Dari tabel 1 diatas dapat dijelaskan bahwa hasil pengamatan terhadap penerapan pendekatan pembelajaran saintifik sebelum dilakukan penelitian ratarata 58 dengan kriteria kurang baik. Dari permasalahan yang ada, sekolah dalam hal ini kepala sekolah di SDN Sumbersari 3 mempunyai tanggung jawab terhadap peningkatan kemampuan guru dalam menerapkan pendekatan pembelajaran saintifik. Hal ini dikarenakan guru sebagai salah satu penentu keberhasilan pencapaian tujuan pembelajaran, dituntut mampu mengorganisasikan dan menciptakan suatu sistem lingkungan belajar dengan berbagai metode sehingga siswa dapat melakukan kegiatan belajar secara lebih optimal (Kirom, 2017). Guru merupakan figur sentral yang berinteraksi langsung dengan siswa dalam pembelajaran, sehingga berperan penting dalam membimbing siswa agar berkualitas baik secara akademis, keahlian, kematangan emosional, moral serta spiritual (Alawiyah, 2013).

Oleh karena itu diperlukan tindakan dan strategi kongkrit untuk menyelesaikan masalah terkait rendahnya kemampuan guru dalam menerapkan pembelajaran saintifik. Salah satu strategi yang dapat diterapkan yaitu Lesson Study. Lesson Study merupakan model pembelajaran yang dapat meningkatkan kemampuan kolaboratif, dimana siswa dan guru dapat bekerjasama untuk memecahkan masalah secara efektif (Dewi et al., 2016). Lesson Study adalah model pembinaan (pelatihan) profesi pendidik melalui pengkajian pembelajaran secara kolaboratif dan berkelanjutan berlandaskan prinsip-prinsip kolegialitas dan mutual learning untuk membangun komunitas belajar.

Lesson Study merupakan proses kolaboratif pada sekelompok guru ketika mengidentifikasikan masalah pembelajaran, merancang suatu skenario pembelajaran (yang meliputi kegiatan mencari buku dan artikel mengenai topik yang akan diajarkan); membelajarkan peserta didik sesuai dengan skenario (salah seorang guru melaksanakan pembelajaran sedangkan yang lain mengamati), mengevaluasi dan merevisi skenario pembelajaran, membelajarkan lagi skenario pembelajaran yang telah direvisi, mengevaluasi lagi pembelajaran dan membagikan hasilnya dengan guru-guru lain (mendiseminasikannya). Penerapan Lesson Study merupakan wahana yang tepat untuk mengembalikan guru kepada budaya mengajar 
yang profesiaonal dan proporsional yang berorientasi pada perbaikan kualitas pembelajaran untuk mencapai keterampilan kolaboratif, berpikir kritis, kreatif dan komunikatif (Putra \& Nurlizawati, 2019).

Dari beberapa pernyataan di atas dapat disimpulkan bahwa lesson study adalah sebuah model pembinaan guru dalam meningkatkan kinerja guru yang dilakukan secara bersama-sama oleh sekelompok guru demi mewujudkan kinerja guru ke arah yang lebih baik lagi. Lesson Study sendiri bukan merupakan metode atau strategi pembelajaran tetapi kegiatan Lesson Study dapat menerapkan metode atau strategi pembelajaran yang sesuai dengan situasi, kondisi, dan permasalahan yang dihadapi guru. Menurut Rozak \& Fauziah (2013) Lesson Study memiliki beberapa tujuan sebagai berikut; (1) model Lesson Study sebagai upaya pembinaan kompetensi pedagogik guru bahasa Indonesia, (2) dampak implementasi Lesson Study terhadap profil kompetensi pedagogik, 3) dampak Lesson Study terhadap mutu pembelajaran di dalam kelas. Dalam penelitian ini penulis ingin menerapkan Lesson Study untuk melihat kemampuan guru dalam mempraktekkan pembelajaran saintifik.

\section{METODE}

Penelitian ini menggunakan metode penelitian sekolah. Subjek penelitian ini adalah guru di SDN Sumbersari 3 kecamatan Maesan kabupaten Bondowoso tahun pelajaran 2015/2016 yang berjumlah 8. Dari 8 guru tersebut berstatus sebagai pegawai negeri sipil (PNS) sebanyak 6 orang dan yang bestatus guru tidak tetap (GTT) sebanyak 2 orang. Jenis data yang digunakan penelitian ini berupa data kuantitatif dan kualitatif. Data kuantitatif adalah data dalam wujud angka-angka untuk mengetahui kualitas penilaian autentik yang disusun guru. Sedangkan data data kualitatif berupa hasil wawancara terhadap tingkat kemampuan guru dalam penyusunan penilaian autentik yang dihasilkan.

\section{HASIL DAN PEMBAHASAN}

Hasil penelitian pada siklus 1 diperoleh dari 3 kegiatan observasi yaitu obervasi aktifitas guru, observasi aktifitas kepala sekolah dan observasi terhadap penerapan pendekatan pembelajaran saintifik. Hasil dari observasi pada siklus 1 dapat dijelaskan sebagai berikut.

a. Aktiftas kepala sekolah 
Hasil observasi terhadap aktiftas kepala sekolah pada tindakan siklus 1 dapat dijelaskan pada tabel 2 sebagai berikut.

Tabel 2 Rekapitulasi hasil observasi terhadap aktiftas kepala sekolah siklus 1

\begin{tabular}{clc}
\hline No & \multicolumn{1}{c}{ Aspek penilaian guru } & Rata - rata \\
\hline 1 & $\begin{array}{l}\text { Kesesuaian materi dengan tujuan } \\
\text { pembelajaran }\end{array}$ & 3 \\
\hline 2 & Sitematika dan kejelasan materi & 4 \\
\hline 3 & Kemampuan menyampaikan materi & 4 \\
\hline 4 & Penguasaan materi & 3 \\
\hline 5 & Kemampuan mengelola kelas & 4 \\
\hline 6 & Kemampuan mengelola waktu & 3 \\
\hline 7 & Penggunaan alat bantu/media belajar & 4 \\
\hline 8 & Penguasaan masalah & 4 \\
\hline 9 & Interaksi dengan peserta & 4 \\
\hline 10 & Kemampuan menjawab pertanyaan & 3 \\
\hline & Jumlah skor tercapai & $\mathbf{3 6}$ \\
\hline & Skor maksimal & $\mathbf{4 0}$ \\
\hline & Rata-rata & $\mathbf{9 0}$ \\
\hline & Kriteria & Sangat baik \\
\hline
\end{tabular}

Dari hasil observasi terhadap penyajian yang dilakukan oleh kepala sekolah pada tindakan silklus 1 seperti pada tabel 2 tersebut rata-rata sudah sangat baik dengan hasil penilaian sebesar 90 .

b. Aktifitas Guru.

Proses diskusi siklus pertama guru diberikan lembar kerja guru, kegiatan selanjutnya guru melakukan kegiatan diskusi dengan kelompoknya untuk membahas dan menyelesaikan tugas yang terdapat dalam LK tersebut. Kepala sekolah hanya berkeliling kesemua kelompok untuk memastikan hasil kerja dalam kelompok tersebut dan melakukan penilaian aktifitas diskusi yang dilakukan guru.

Hasil pengamatan terhadap aktifitas guru dalam kegiatan diskusi siklus 1 dapat dijelaskan pada tabel 3 sebagai berikut.

Tabel 3 Rekapitulasi Hasil Penilaian Aktifitas Guru Siklus 1

\begin{tabular}{clc}
\hline No & \multicolumn{1}{c}{ Aspek penilaian guru } & Rata - rata \\
\hline 1 & Berpartisipasi aktif & 78 \\
\hline 2 & Tanggung jawab & 84 \\
\hline 3 & Disiplin dalan mengikuti diskusi guru & 81 \\
\hline 4 & Memusatkan perhatian pada materi & 78 \\
\hline & Jumlah skor tercapai & $\mathbf{3 2 1}$ \\
\hline
\end{tabular}




\begin{tabular}{ccc}
\hline No & Aspek penilaian guru & Rata - rata \\
\hline Skor maksimal & $\mathbf{4 0 0}$ \\
\hline Rata-rata & $\mathbf{8 0}$ \\
\hline Kriteria & Baik \\
\hline
\end{tabular}

Berdasarkan 4 aspek observasi pada tabel 3 di atas, didapatkan persentase aktifitas guru pada kegiatan tindakan siklus 1 rata-rata 80 dengan kriteria baik. Dengan nilai tertinggi pada aspek tanggung jawab guru dalam kegiatan sebesar 84, sedangkan nilai terendah pada aspek partisipasi aktif guru dan kemampuan guru dalam memusatkan perhatian pada materi pada kegiatan sebesar 78 .

\section{Hasil pengamatan terhadap pelaksanaan pembelajaran di kelas dengan menerapkan pendekatan pembelajaran saintifik siklus 1}

Praktik pelaksanaan pembelajaran di kelas dengan menerapkan pendekatan pembelajaran saintifik dilakukan oleh masing-masing guru di dalam kelas. Praktek pelaksanaan pembelajaran di kelas dengan menerapkan pendekatan pembelajaran saintifik pada kurikulum 2013 dilakukan secara bergantian dengan menggunakan 2 observer yaitu 1 guru dan 1 kepala sekolah. Hasil observasi dan penilaian terhadap pelaksanaan pembelajaran di kelas dengan menerapkan pendekatan pembelajaran saintifik pada tindakan siklus 1 dapat djelaskan pada tabel 4 sebagai berikut.

Tabel 4 Rekapitulasi hasil pengamatan terhadap pelaksanaan pembelajaran di kelas dengan menerapkan pendekatan pembelajaran saintifik siklus 1

\begin{tabular}{|c|c|c|c|}
\hline No & Aspek penilaian & $\begin{array}{c}\text { Jumlah } \\
\text { skor }\end{array}$ & $\begin{array}{r}\text { Rata- } \\
\text { rata }\end{array}$ \\
\hline 1 & $\begin{array}{l}\text { Memfasilitasi dan menyajikan kegiatan untuk } \\
\text { mengamati }\end{array}$ & 26 & 81 \\
\hline 2 & $\begin{array}{l}\text { Memfasilitasi dan menyajikan kegiatan untuk } \\
\text { bertanya }\end{array}$ & 27 & 84 \\
\hline 3 & $\begin{array}{l}\text { Memfasilitasi dan menyajikan kegiatan untuk } \\
\text { mengumpulkan informasi }\end{array}$ & 25 & 78 \\
\hline 4 & $\begin{array}{l}\text { Memfasilitasi dan menyajikan kegiatan untuk } \\
\text { mengasosiasikan data dan informasi yang } \\
\text { dikumpulkan }\end{array}$ & 26 & 81 \\
\hline 5 & $\begin{array}{l}\text { Memfasilitasi dan menyajikan kegiatan untuk } \\
\text { mengkomunikasikan pengetahuan } \\
\text { keterampilan yang diperolehnya }\end{array}$ & 26 & 81 \\
\hline & Jumlah skor & 130 & 405 \\
\hline & Skor maksimal & 151 & 500 \\
\hline & Rata-rata & \multicolumn{2}{|c|}{81} \\
\hline & Kriteria & \multicolumn{2}{|c|}{ Baik } \\
\hline
\end{tabular}


Dari tabel diatas dapat dijelaskan bahwa hasil pengamatan terhadap penerapan pendekatan pembelajaran saintifik pada tindakan siklus 1 rata-rata 81 dengan kriteria baik. Hasil penilaian tertinggi pada aspek memfasilitasi dan menyajikan kegiatan untuk bertanya rata-rata 84 dengan kriteria baik, sedangkan hasil penilaian terendah pada aspek memfasilitasi dan menyajikan kegiatan untuk mengumpulkan informasi rata-rata 78 dengan krteria baik.

Hasil observasi dan penilaian terhadap aktifitas kepala sekolah dalam melakukan tindakan berupa model pembelajaran lesson study pada siklus 1 pada indikator sistematika dan kejelasan materi, kemampuan menyampaikan materi, kemampuan mengelola kelas, penggunaan alat bantu/media belajar, penguasaan masalah dan interaksi dengan peserta sudah dilakukan dengan sangat baik. Sedangkan pada aspek kesesuaian materi dengan tujuan pembelajaran, penguasaan materi dan kemampuan mengelola waktu, dan kemampuan menjawab pertanyaan sudah dilakukan dengan baik. Guru sudah tidak kesulitan lagi dalam menerapkan kegiatan pembelajaran untuk mengembangkan keterampilan siswa dalam mengumpulkan informasi/mencoba (exploring) melalui kegiatan eksperimen, membaca sumber lain selain buku teks, mengamati objek/kejadian/aktifitas.

Guru telah menerapkan kegiatan pembelajaran untuk mengembangkan keterampilan siswa dalam menalar/mengasosiasi (Associating) melalui berbagai kegiatan diantaranya adalah mengolah/membahas informasi yang bersifat menambah keleluasaan dan kedalaman, mengolah/membahas infomasi yang bersifat mencari solusi. Namun pada kegiatan siklus 1 ini masih ditemukan permasahan yaitu kesulitan guru dalam menerapkan kegiatan pembelajaran untuk mengembangkan keterampilan siswa dalam menalar/mengasosiasi (Associating) pada aspek membuat suatu kesimpulan. Hasil observasi tersebut ditemukan ketika guru memerintahkan siswa untuk menyimpulkan suatu permasalahan yang sudah dibahas.

Hasil refleksi aktifitas guru pada aspek partisipasi guru pada kegiatan diskusi kelompok dalam mengerjakan tugas yang diberikan kepala sekolah masih ditemukan beberapa guru yang masih terlihat belum aktif ikut berpartisipasi pada kegiatan diskusi dan pengerjaan tugas. Guru hanya diam dan asyik bercerita sendiri tentang masalah yang tidak ada hubungannya dengan materi yang dibahas. Sesuai 
dengan hasil observasi tersebut yang menjadi penyebabnya adalah guru tersebut tidak diberikan peran atau kepercayaan untuk menyelesaikan tugas pada kelompok tersebut. Pada aspek tanggungjawab ditemukan ada beberapa guru yang terlihat malas untuk mengumpulkan tugas. Pada aspek kedisplinan dalan mengikuti diskusi guru pada kegiatan diskusi masih ditemukan beberapa guru yang sering keluar dari dalam kelas untuk bersenda gurau dengan teman yang lain. Sedangkan pada aspek pemusatan perhatian pada materi, rata-rata guru sudah terlihat perhatian terhadap materi yang di jelaskan kepala sekolah.

Namun pada kegiatan siklus 1 ini masih ditemukan permasalahan yaitu kesulitan guru dalam menerapkan kegiatan pembelajaran untuk mengembangkan keterampilan siswa dalam bertanya pada tataran analisis, sintesis dan evaluasi suatau permasalahan yang disuguhkan pada siswa. Selain itu terdaapat permasalahan terkati kesulitan guru dalam menerapkan kegiatan pembelajaran untuk mengembangkan keterampilan siswa dalam mengumpulkan informasi/mencoba (exploring) melalui wawancara dengan nara sumber. Hasil observasi tersebut ditemukan ketika guru memerintahkan siswa untuk melakukan kegiatan wawancara dan kemudian disuruh untuk merangkum hasil wawancaranya ternyata masih tidak sesuai dengan tema wawancaranya.

Perbandingan rekapitulasi hasil pengamatan terhadap penerapan pendekatan pembelajaran saintifik sebelum dilakukan penelitian dan sesudah dilakukan penelitian siklus 1 dapat dijelaskan pada tabel 5 sebagai berikut:

Tabel 5 Perbandingan hasil pengamatan terhadap penerapan pendekatan pembelajaran saintifik pra siklus dan siklus 1

\begin{tabular}{clccc}
\hline \multirow{2}{*}{ No } & \multicolumn{1}{c}{ Aspek penilaian } & \multicolumn{2}{c}{ Rata-rata } \\
\cline { 3 - 5 } & $\begin{array}{c}\text { Pra } \\
\text { siklus }\end{array}$ & Siklus 1 \\
\hline 1 & $\begin{array}{l}\text { Memfasilitasi dan menyajikan kegiatan untuk } \\
\text { mengamati }\end{array}$ & 56 & 81 \\
\hline 2 & $\begin{array}{l}\text { Memfasilitasi dan menyajikan kegiatan untuk } \\
\text { bertanya }\end{array}$ & 63 & 84 \\
\hline 3 & $\begin{array}{l}\text { Memfasilitasi dan menyajikan kegiatan untuk } \\
\text { mengumpulkan informasi }\end{array}$ & 53 & 78 \\
\hline 4 & $\begin{array}{l}\text { Memfasilitasi dan menyajikan kegiatan untuk } \\
\text { mengasosiasikan data dan informasi yang } \\
\text { dikumpulkan }\end{array}$ & 56 & 81 \\
\hline 5 & $\begin{array}{l}\text { Memfasilitasi dan menyajikan kegiatan untuk } \\
\text { mengkomunikasikan pengetahuan } \\
\text { keterampilan yang diperolehnya }\end{array}$ & 63 & 81 \\
\hline
\end{tabular}




\begin{tabular}{cccc}
\hline \multirow{2}{*}{ No } & Aspek penilaian & \multicolumn{2}{c}{ Rata-rata } \\
\cline { 2 - 3 } & $\begin{array}{c}\text { Pra } \\
\text { siklus }\end{array}$ & Siklus 1 \\
\hline Jumlah skor & 291 & 405 \\
\hline Skor maksimal & 500 & 500 \\
\hline Rata-rata & 58 & 81 \\
\hline Kriteria & $\begin{array}{c}\text { Kurang } \\
\text { baik }\end{array}$ & Baik \\
\hline
\end{tabular}

Dari tabel 5 diatas dapat di jelaskan bahwa perbandingan hasil pengamatan terhadap penerapan pendekatan pembelajaran saintifik sebelum dilakukan penelitian pra dan sesudah dilakukan penelitian pada siklus 1 tersebut diatas telah terjadi peningkatan kemampuan guru dalam menerapkan pendekatan pembelajaran saintifik pada kurikulum 2013 sebelum dilakukan penelitian rata-rata 58 dengan kriteria kurang baik, sedangkan hasil penilaian pada siklus 1 rata-rata 81 dengan kriteria baik.

\section{Siklus Kedua}

Hasil penelitian pada siklus 2 dapat dijelaskan sebagai berikut.

a. Aktiftas kepala sekolah

Hasil observasi terhadap Aktiftas kepala sekolah pada tindakan siklus 2 dapat dijelaskan pada tabel 6 sebagai berikut.

Tabel 6 Rekapitulasi hasil observasi terhadap kepala sekolah Siklus 2

\begin{tabular}{clc}
\hline No & \multicolumn{1}{c}{ Aspek penilaian guru } & Rata - rata \\
\hline 1 & Kesesuaian materi dengan tujuan pembelajaran & 4 \\
\hline 2 & Sitematika dan kejelasan materi & 4 \\
\hline 3 & Kemampuan menyampaikan materi & 4 \\
\hline 4 & Penguasaan materi & 4 \\
\hline 5 & Kemampuan mengelola kelas & 4 \\
\hline 6 & Kemampuan mengelola waktu & 4 \\
\hline 7 & Penggunaan alat bantu/media belajar & 4 \\
\hline 8 & Penguasaan masalah & 4 \\
\hline 9 & Interaksi dengan peserta & 4 \\
\hline 10 & Kemampuan menjawab pertanyaan & 3 \\
\hline & Jumlah skor tercapai & $\mathbf{3 9}$ \\
\hline & Skor maksimal & $\mathbf{4 0}$ \\
\hline & Rata-rata & $\mathbf{9 8}$ \\
\hline & Kriteria
\end{tabular}


Dari hasil observasi terhadap penyajian yang dilakukan oleh kepala sekolah pada tindakan silklus 2 seperti pada tabel 6 tersebut rata-rata sudah sangat baik dengan hasil penilaian sebesar 98 .

\section{Aktifitas Guru.}

Hasil pengamatan terhadap aktifitas guru dalam kegiatan diskusi siklus 2 dapat dijelaskan pada tabel 7 sebagai berikut.

Tabel 7 Rekapitulasi Hasil Penilaian Aktifitas Guru Siklus 2

\begin{tabular}{clc}
\hline No & Aspek penilaian guru & Rata - rata \\
\hline 1 & Berpartisipasi aktif & 84 \\
\hline 2 & Tanggung jawab & 100 \\
\hline 3 & Disiplin dalan mengikuti diskusi guru & 91 \\
\hline 4 & Memusatkan perhatian pada materi & 81 \\
\hline & Jumlah skor tercapai & $\mathbf{3 5 6}$ \\
\hline & Skor maksimal & $\mathbf{4 0 0}$ \\
\hline & Rata-rata & $\mathbf{9 0}$ \\
\hline & Kriteria & Sangat baik \\
\hline
\end{tabular}

Berdasarkan 4 aspek observasi pada tabel 7 diatas, didapatkan persentase aktifitas guru pada kegiatan tindakan siklus 2 rata-rata 90 dengan kriteria sangat baik. Dengan nilai tertinggi pada aspek tanggung jawab guru dalam kegiatan sebesar 100, sedangkan nilai terendah pada aspek memusatkan perhatian pada materi pada kegiatan sebesar 90.

Hasil observasi dan penilaian terhadap pelaksanaan pembelajaran di kelas dengan menerapkan pendekatan pembelajaran saintifik pada tindakan siklus 2 dapat djelaskan pada tabel 8 sebagai berikut.

Tabel 8 Rekapitulasi hasil pengamatan terhadap pelaksanaan pembelajaran di kelas dengan menerapkan pendekatan pembelajaran saintifik siklus 2

\begin{tabular}{clccc}
\hline No & \multicolumn{2}{c}{ Aspek penilaian } & $\begin{array}{c}\text { Jumlah } \\
\text { skor }\end{array}$ & $\begin{array}{c}\text { Rata- } \\
\text { rata }\end{array}$ \\
\hline 1 & $\begin{array}{l}\text { Memfasilitasi dan menyajikan kegiatan untuk } \\
\text { mengamati }\end{array}$ & 28 & 88 \\
\hline 2 & $\begin{array}{l}\text { Memfasilitasi dan menyajikan kegiatan untuk } \\
\text { bertanya }\end{array}$ & 32 & 100 \\
\hline 3 & $\begin{array}{l}\text { Memfasilitasi dan menyajikan kegiatan untuk } \\
\text { mengumpulkan informasi }\end{array}$ & 29 & 91 \\
\hline 4 & $\begin{array}{l}\text { Memfasilitasi dan menyajikan kegiatan untuk } \\
\text { mengasosiasikan data dan informasi yang } \\
\text { dikumpulkan }\end{array}$ & 28 & 88 \\
\hline
\end{tabular}




\begin{tabular}{ccccc}
\hline No & Aspek penilaian & $\begin{array}{c}\text { Jumlah } \\
\text { skor }\end{array}$ & $\begin{array}{c}\text { Rata- } \\
\text { rata }\end{array}$ \\
\hline $\begin{array}{l}\text { Memfasilitasi dan menyajikan kegiatan untuk } \\
\text { mengkomunikasikan pengetahuan } \\
\text { keterampilan yang diperolehnya }\end{array}$ & dan & 28 & 88 \\
\hline Jumlah skor & & $\mathbf{1 4 5}$ & $\mathbf{4 5 5}$ \\
\hline Skor maksimal & $\mathbf{1 5 1}$ & $\mathbf{5 0 0}$ \\
\hline Rata-rata & \multicolumn{3}{c}{$\mathbf{9 1}$} \\
\hline Kriteria & \multicolumn{3}{c}{ Sangat baik } \\
\hline
\end{tabular}

Dari tabel 8 diatas dapat dijelaskan bahwa hasil pengamatan terhadap penerapan pendekatan pembelajaran saintifik pada tindakan siklus 2 rata-rata 91 dengan kriteria sangat baik. Hasil penilaian tertinggi pada aspek memfasilitasi dan menyajikan kegiatan untuk bertanya rata-rata 100 dengan kriteria sangat baik, sedangkan hasil penilaian terendah pada aspek memfasilitasi dan menyajikan kegiatan untuk mengamati, memfasilitasi dan menyajikan kegiatan untuk mengasosiasikan data dan informasi yang dikumpulkan dan memfasilitasi dan menyajikan kegiatan untuk mengkomunikasikan pengetahuan dan keterampilan yang diperolehnya rata-rata 91 dengan krteria sangat baik.

Hasil refleksi menyebutkan bahwa aktifitas guru pada tindakan siklus 2 sudah sangat baik. Guru sudah mampu berpatisipasi dalam kelompok dengan baik. pada kegiatan tersebut guru sudah aktif ikut berpartisipasi pada kegiatan diskusi dan pengerjaan tugas. Pada aspek tanggungjawab menunjukkan bahwa masingmasing guru sudah memiliki tanggungjawab yang sangat baik. Hal ini tampak pada rajinnya guru ketika guru mengumpulkan tugas. Aspek kedisplinan dalan mengikuti diskusi guru pada kegiatan siklus 2 rata-rata sudah sangat baik. Hal ini tampak guru sudah mampau tepat waktu pada kegiatan dan mengumpulkan tugas yang diberikan kepala sekolah. Sedangkan pada aspek pemusatan perhatian pada materi rata-rata guru sudah baik, hal ini terlihat dari perhatian guru terhadap materi yang di jelaskan kepala sekolah.

Guru sudah tidak kesulitan lagi dalam menerapkan kegiatan pembelajaran untuk mengembangkan keterampilan siswa bertanya pada tingkatan pengetahuan, pemahaman, dan penerapan, analisis, sintesis dan evaluasi. Dalam menerapkan kegiatan pembelajaran guru mengembangkan keterampilan siswa dalam mengumpulkan informasi/mencoba (exploring) melalui kegiatan eksperimen, membaca sumber lain selain buku teks,mengamati objek/kejadian/aktifitas, dan 
wawancara dengan nara sumber. Guru juga menerapkan kegiatan pembelajaran untuk mengembangkan keterampilan siswa dalam menalar/mengasosiasi (Associating) melalui berbagai kegiatan diantaranya adalah mengolah/membahas informasi yang bersifat menambah keleluasaan dan kedalaman, mengolah/membahas infomasi yang bersifat mencari solusi, sampai diperoleh, dan membuat suatu kesimpulan.

Perbandingan rekapitulasi hasil pengamatan terhadap penerapan pendekatan pembelajaran saintifik sebelum dilakukan penelitian dan sesudah dilakukan penelitian siklus 2 dapat dijelaskan pada tabel 4.8 sebagai berikut

Tabel 9 Perbandingan hasil pengamatan terhadap penerapan pendekatan pembelajaran saintifik pra siklus, siklus 1 dan siklus 2

\begin{tabular}{|c|c|c|c|c|}
\hline \multirow[b]{2}{*}{ No } & \multirow[b]{2}{*}{ Aspek penilaian } & \multicolumn{3}{|c|}{ Rata-rata } \\
\hline & & $\begin{array}{c}\text { Pra } \\
\text { siklus }\end{array}$ & Siklus 1 & Siklus 2 \\
\hline 1 & $\begin{array}{l}\text { Memfasilitasi dan menyajikan kegiatan untuk } \\
\text { mengamati }\end{array}$ & 56 & 81 & 88 \\
\hline 2 & $\begin{array}{l}\text { Memfasilitasi dan menyajikan kegiatan untuk } \\
\text { bertanya }\end{array}$ & 63 & 84 & 100 \\
\hline 3 & $\begin{array}{l}\text { Memfasilitasi dan menyajikan kegiatan untuk } \\
\text { mengumpulkan informasi }\end{array}$ & 53 & 78 & 91 \\
\hline 4 & $\begin{array}{l}\text { Memfasilitasi dan menyajikan kegiatan untuk } \\
\text { mengasosiasikan data dan informasi yang } \\
\text { dikumpulkan }\end{array}$ & 56 & 81 & 88 \\
\hline 5 & $\begin{array}{l}\text { Memfasilitasi dan menyajikan kegiatan untuk } \\
\text { mengkomunikasikan pengetahuan dan } \\
\text { keterampilan yang diperolehnya }\end{array}$ & 63 & 81 & 88 \\
\hline & Jumlah skor & 291 & 405 & 455 \\
\hline & Skor maksimal & 500 & 500 & 500 \\
\hline & Rata-rata & 58 & 81 & 91 \\
\hline & Kriteria & $\begin{array}{c}\text { Kurang } \\
\text { baik }\end{array}$ & Baik & $\begin{array}{c}\text { Sangat } \\
\text { baik }\end{array}$ \\
\hline
\end{tabular}

Dari tabel 9 diatas dapat di jelaskan bahwa perbandingan hasil pengamatan terhadap penerapan pendekatan pembelajaran saintifik sebelum dilakukan penelitian pra dan sesudah dilakukan penelitian pada siklus 1 tersebut diatas telah terjadi peningkatan kemampuan guru dalam menerapkan pendekatan pembelajaran saintifik pada kurikulum 2013 sebelum dilakukan penelitian rata-rata 58 dengan kriteria kurang baik, hasil penilaian pada siklus 1 rata-rata 81 dengan kriteria baik, sedangkan hasil penilaian pada siklus 2 rata-rata 91 dengan kriteria sangat baik. 
Hasil wawancara dilakukan pada akhir siklus 2 dengan berpedoman pada daftar pertanyaan berjumlah 5 butir pertanyaan yang telah dibuat peneliti sebelummnya. Berikut ini merupakan data hasil wawancara dengan salah satu guru di SDN Sumbersari 3 kecamatan Maesan kabupaten Bondowoso.

Pertanyaan pertama yaitu pendapat guru tentang penerapan pendekatan saintifik pada kurikulum 2013 di masing-masing kelas. Guru tersebut mengatakan bahwa pada kondisi tertentu saya masih kesulitan dalam melakukan kegiatan 5M (mengamati, menanya, mengumpulkan informasi/mencoba, menalar/mengasosiasi (associating) dan mengkomunikasikan. Hasil jawaban guru tersebut berbeda ketika sebelum dilakukan penelitian. Sebelum dilakukaan peneltian guru mengatakan bahwa rata-rata guru sudah melakukan perubahan dalam melakukan kegiatan $5 \mathrm{M}$ (mengamati, menanya, mengumpulkan informasi/mencoba, menalar/mengasosiasi (Associating) dan mengkomunikasikan, hanya perlu adanya pengalaman dalam menerapkan pembelajaran saintifik pada materi yang berbeda.

Pertanyaan kedua tentang kendala bagi guru dalam menerapkan keterampilan mengamati bagi siswa. Guru tersebut mengatakan bahwa tidak menemukan kesulitan dalam menerapkan kegiatan pembelajaran untuk mengembangkan keterampilan siswa dalam mengamati, yang terdiri dari kegiatan melihat, menyimak, mendengar dan membaca. Hasil jawaban guru tersebut berbeda ketika sebelum dilakukan penelitian. Sebelum dilakukaan peneltian guru mengatakan bahwa rata-rata guru masih kesulitan dalam menerapkan kegiatan pembelajaran untuk mengembangkan keterampilan siswa dalam melakukan kegiatan menyimak dari bacaan atau cerita yang disajikan.

Pertanyaan ke tiga tentang kendala bagi guru dalam menerapkan keterampilan menanya (questioning). Hasil jawaban guru tersebut mengatakan bahwa para guru tidak menemukan kesulitan dalam menerapkan kegiatan pembelajaran untuk mengembangkan keterampilan siswa dalam kegiatan bertanya pada tingkatan pengetahuan, pemahaman, dan penerapan, analisis, sintesis dan evaluasi. Hasil jawaban guru tersebut berbeda ketika sebelum dilakukan penelitian. Sebelum dilakukaan peneltian guru mengatakan bahwa para guru masih kesulitan dalam menerapkan kegiatan pembelajaran untuk mengembangkan keterampilan siswa dalam melakukan kegiatan bertanya. Rata-rata hanya mampu melakukan 
kegiatan bertanya hanya pada tingatan pemahaman belum bertanya sesuatu yang bersifat analisis misalnya dengan menggunakan kalimat tanya "mengapa".

Pertanyaan ke empat tentang kendala bagi guru dalam menerapkan keterampilan mengumpulkan informasi/mencoba (exploring) bagi siswa. Hasil jawaban guru tersebut mengatakan bahwa para guru sudah tidak menemukan kesulitan dalam menerapkan kegiatan pembelajaran untuk mengembangkan keterampilan siswa dalam melakukan kegiatan mengumpulkan informasi/mencoba (exploring) melalui berbagai kegiatan diantaranya adalah eksperimen, membaca sumber lain selain buku teks, mengamati objek/kejadian/ aktifitas, dan wawancara dengan nara sumber. Hasil jawaban guru tersebut berbeda ketika hasil wawancara sebelum dilakukan penelitian yang mengatakan bahwa para guru masih kesulitan dalam menerapkan kegiatan pembelajaran untuk mengembangkan keterampilan siswa dalam melakukan kegiatan mencari informasi di dunia maya misalnya menggunakan gogle pencarian.

Pertanyaan ke lima tentang kendala bagi guru dalam menerapkan keterampilan menalar/mengasosiasi (Associating) bagi siswa. Hasil jawaban guru tersebut mengatakan bahwa para guru sudah tidak menemukan kesulitan dalam menerapkan kegiatan pembelajaran untuk mengembangkan keterampilan siswa dalam menalar/mengasosiasi (Associating) melalui berbagai kegiatan diantaranya adalah mengolah/membahas informasi yang bersifat menambah keleluasaan dan kedalaman, mengolah/membahas infomasi yang bersifat mencari solusi, sampai diperoleh, dan membuat suatu kesimpulan. Hasil jawaban guru tersebut berbeda ketika hasil wawancara sebelum dilakukan penelitian yang mengatakan bahwa para guru masih kesulitan dalam menerapkan kegiatan pembelajaran untuk mengembangkan keterampilan siswa dalam melakukan kegiatan menyimpulkan dari materi yang sedang dibahas

Pertanyaan ke enam tentang kendala bagi guru dalam menerapkan keterampilan mengkomunikasikan/ menyajikan bagi siswa. Hasil jawaban guru tersebut mengatakan bahwa para guru tidak menemukan kesulitan dalam menerapkan kegiatan pembelajaran untuk mengembangkan keterampilan siswa dalam melakukan kegiatan mengkomunikasikan/ menyajikan melalui berbagai kegiatan diantaranya adalah membuat kesimpulan dan melakukan presentasi. Hasil 
jawaban guru tersebut berbeda ketika hasil wawancara sebelum dilakukan penelitian yang mengatakan bahwa guru masih kesulitan dalam menerapkan kegiatan pembelajaran untuk mengembangkan keterampilan siswa dalam menyimpulkan materi yang sudah dibahas dan menumbuhkan kepercayaan diri siswa dalam melakukan presentasi.

\section{SIMPULAN}

Berdasarkan hasil penelitian diatas dapat diambil kesimpulan bahwa tindakan kepala sekolah menggunakan model pembelajaran Lesson Study untuk meningkatkan keterampilan guru dalam menerapkan pembelajaran santifik dinyatakan berhasil. Hal ini dibuktikan dengan peningkatan nilai rata-rata aktifitas kepala sekolah yang terus meningkat yang berawal dari nilai 91 pada siklus 1 menjadi 98 pada siklus 2. Selain itu nilai rata-rata praktik pembelajaran juga terus mengalami peningkatan yaitu 58 pada pra siklus kemudian meningkat menjadi 81 pada siklus 1 dan 91 pada siklus 2. Kompetensi guru dalam menerapkan pemebelajaran saintifik dari pra siklus sampai pada siklus 2. Sebagai saran untuk penelitian lanjutan sebaiknya diteliti variabel lain yang relevan dengan penerapan model Lesson Study.

\section{DAFTAR RUJUKAN}

Alawiyah, F. (2013). Peran Guru dalam Kurikulum 2013. Aspirasi, 4(1), 65-74.

Retrieved from http://jurnal.dpr.go.id/index.php/aspirasi/article/view/480

Chuntala, A. D. W. (2019). Scientific approach in 21st century learning in

Indonesian language learning vocational school of pharmacy. International

Journal of Active Learning, 4(2), 71-77. Retrieved from

http://journal.unnes.ac.id/nju/index.php/ijal

Daryanto, \& Sudjendro, H. (2014). Siap Menyongsong Kurikulum 2013.

Yogyakarta: Gava Media.

Dewi, M. R., Mudakir, I., \& Murdiyah, S. (2016). Pengaruh Model Pembelajaran

Kolaboratif Berbasis Lesson Study terhadap Kemampuan Berpikir Kritis

Siswa. The Effect of Collaborative Learning Model with Lesson Study on

Student Critical Thingking. Jurnal Edukasi Unej, III(2), 29-33.

Kirom, A. (2017). Peran Guru Dan Peserta Didik Dalam Proses Pembelajaran

Berbasis Multikultural. Al Murabbi, 3(1), 69-80. Retrieved from 
http://jurnal.yudharta.ac.id/v2/index.php/pai/article/view/893

Mahsun. (2013). Lampung Sukses Menyelenggarakan Penguatan Kompetensi

Guru Bahasa Indonesia untuk Implementasi Kurikulum 2013. Retrieved from http://badanbahasa.kemdikbud.go.id/lamanbahasa/content/lampung-suksesmenyelenggarakan-penguatan-kompetensi-guru-bahasa-indonesia-untukimplementas

Majid, A. (2014). Pembelajaran Tematik Terpadu. Bandung: PT. Remaja Rosdakarya.

Musfiqon, \& Nurdyansyah. (2015). Pendekatan Pembelajaran Saintifik (1st ed.). Retrieved from http://eprints.umsida.ac.id/306/1/BUku Saintifik.pdf

Mustakim, A., \& Jumini, S. (2020). Pengaruh Penggunaan Modul Pembelajaran Fisika Dengan Pendekatan Saintific Berbasis Riset Untuk Meningkatkan Literasi Sains Siswa Kelas VIII DI SMP Takhassus Al- Qur'an 2 Dero Duwur, Di Wonosobo Tahun Ajaran 2018/2019. PROSIDING Seminar Nasional Pendidikan Fisika FITK UNSIQ 2020, 2(1).

Putra, D. M., \& Nurlizawati. (2019). Lesson Study dalam Meningkatkan Ketrampilan 4C (Critical Thingking, Collaborative, Communicative dan Creative) pada Pembelajaran Sosiologi yang Terintegrasi ABS-SBK di SMAN 1 Pasaman. Jurnal Sikola: Jurnal Kajian Pendidikan Dan Pembelajaran, 1(2), 139-146. https://doi.org/10.24036/sikola.v1i2.19

Rozak, A., \& Fauziah, E. (2013). Implementasi Lesson Study Sebagai Upaya Peningkatan Kompetensi Pedagogik Guru Bahasa Indonesia Di SMP Kabupaten Cirebon. Jurnal pendidikan bahasa dan sastra, 13(1). https://doi.org/https://doi.org/10.17509/bs_jpbsp.v13i1.754

Setiawan, A. R. (2019). Penerapan Pendekatan Saintifik dalam Pembelajaran Biologi sebagai Upaya Melatih Literasi Saintifik Siswa Sekolah Menengah. Seminar Nasional Biologi "Inovasi Penelitian Dan Pendidikan Biologi III, 3, 140-145. https://doi.org/10.31227/osf.io/7p8gm

Wibowo, A. (2017). Pengaruh Pendekatan Pembelajaran Matematika Realistik dan Saintifik terhadap Prestasi Belajar, Kemampuan Penalaran Matematis dan Minat Belajar Aji. Jurnal Riset Pendidikan Matematika, 4(1), 1. https://doi.org/10.21831/jrpm.v4i1.10066 